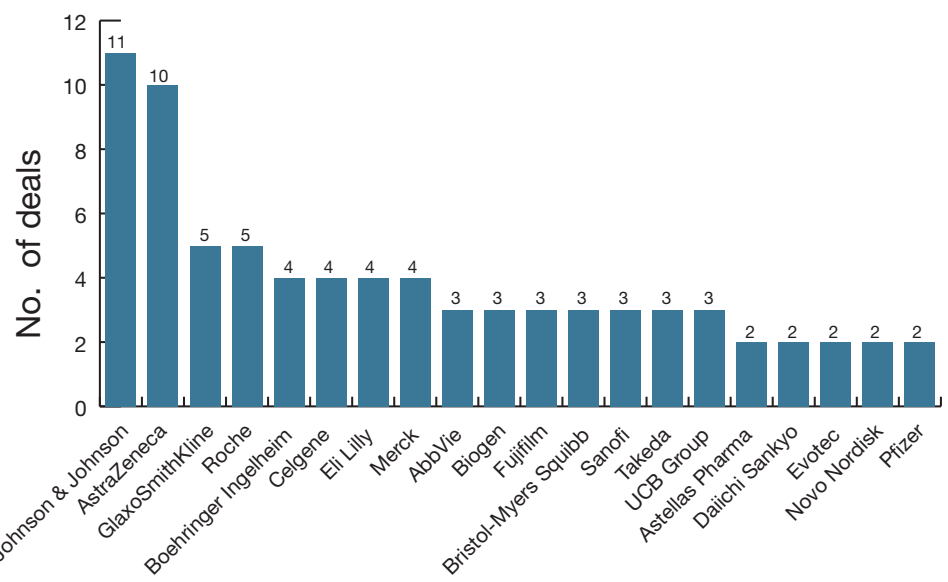

Figure 1 The most-active pharmas and big biotechs with academic or research institute partners in 2016. Source: BCIQ: BioCentury Online Intelligence.

Brady Huggett is Business Editor at Nature Biotechnology.

\title{
PODCAST
}

\section{First rounders: Rachel Haurwitz}

Rachel Haurwitz is co-founder, president and CEO of Caribou Biosciences. In her discussion with Nature Biotechnology, she explains what drew her into the sciences, how her father's journalism career brought their family to Austin, Texas, and how she found herself at the cutting edge of CRISPR technology. http://www. nature. $\mathrm{com} / \mathrm{nbt} /$ podcast/index.html

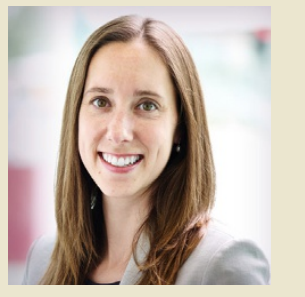

